\title{
A 2021 Update on the Use of Liraglutide in the Modern Treatment of 'Diabesity': A Narrative Review
}

\author{
Mariana Cornelia Tilinca ${ }^{1,2}$, Robert Aurelian Tiuca ${ }^{3, *}$, Alexandru Burlacu ${ }^{4,5, *(D)}$ and Andreea Varga ${ }^{6,7}$ (D) \\ 1 Discipline of Internal Medicine, Department ME2, Faculty of Medicine, "George Emil Palade” University \\ of Medicine, Pharmacy, Science and Technology, 540142 Targu Mures, Romania; mariana.tilinca@umfst.ro \\ 2 Compartment of Diabetology, Emergency Clinical County Hospital of Targu Mures, \\ 540136 Targu Mures, Romania \\ 3 Clinic of Endocrinology, Mures County Clinical Hospital, 540072 Targu Mures, Romania \\ 4 Faculty of Medicine, 'Grigore T. Popa' University of Medicine and Pharmacy, 700115 Iasi, Romania \\ 5 Department of Interventional Cardiology, Cardiovascular Diseases Institute, 700503 Iasi, Romania \\ 6 Department ME2, Faculty of Medicine, "George Emil Palade" University of Medicine, Pharmacy, \\ Science and Technology, 540136 Targu Mures, Romania; andreea.varga@umfst.ro \\ 7 Department of Cardiology II, Emergency Clinical County Hospital of Targu Mures, \\ 540136 Targu Mures, Romania \\ * Correspondence: tiuca.robert@gmail.com (R.A.T.); alexandru.burlacu@umfiasi.ro (A.B.); \\ Tel.: +40-744-488-580 (A.B.)
}

check for updates

Citation: Tilinca, M.C.; Tiuca, R.A.; Burlacu, A.; Varga, A. A 2021 Update on the Use of Liraglutide in the Modern Treatment of 'Diabesity': A Narrative Review. Medicina 2021, 57, 669. https://doi.org/10.3390/ medicina57070669

Academic Editor: Domenico Sergi

Received: 18 June 2021

Accepted: 25 June 2021

Published: 29 June 2021

Publisher's Note: MDPI stays neutral with regard to jurisdictional claims in published maps and institutional affiliations.

Copyright: (c) 2021 by the authors. Licensee MDPI, Basel, Switzerland. This article is an open access article distributed under the terms and conditions of the Creative Commons Attribution (CC BY) license (https:// creativecommons.org/licenses/by/ $4.0 /)$.

\begin{abstract}
Obesity and type 2 diabetes mellitus have become a significant public health problem in the past decades. Their prevalence is increasing worldwide each year, greatly impacting the economic and personal aspects, mainly because they frequently coexist, where the term "diabesity" may be used. The drug class of glucagon-like peptide 1 receptor agonists (GLP-1 RAs) is one of the most modern therapy options in managing these metabolic disorders. This review focuses on the effects of liraglutide, a long-acting GLP-1 RA, in diabesity and non-diabetic excess weight. This drug class improves glycemic control by enhancing insulin secretion from the beta-pancreatic cells and inhibiting glucagon release. Furthermore, other effects include slowing gastric emptying, increasing postprandial satiety, and reducing the appetite and food consumption by influencing the central nervous system, with weight reduction effects. It also reduces cardiovascular events and has positive effects on blood pressure and lipid profile. A lower-dose liraglutide (1.2 or $1.8 \mathrm{mg} / \mathrm{day})$ is used in patients with diabetes, while the higher dose $(3.0 \mathrm{mg} /$ day $)$ is approved as an anti-obesity drug. In this review, we have summarized the role of liraglutide in clinical practice, highlighting its safety and efficacy as a glucose-lowering agent and a weight-reduction drug in patients with and without diabetes.
\end{abstract}

Keywords: type 2 diabetes; obesity; GLP-1 RAs; liraglutide; diabesity

\section{Introduction}

Obesity and type 2 diabetes mellitus (T2DM) are significant public health issues, with both conditions presenting a yearly increasing prevalence worldwide, reaching pandemic proportions that imply economic and personal costs [1]. The use of glucagon-like peptide 1 receptor agonists (GLP-1 RAs) is one of the most modern therapy options in managing these metabolic disorders. The latest data by the World Health Organization (WHO) shows that the prevalence of obesity has tripled since 1975, with over 650 million people worldwide being obese in 2016 [2]. Obesity is typically defined by a body mass index (BMI) of $\geq 30 \mathrm{~kg} / \mathrm{m}^{2}$, although a lower cutoff point of $\geq 27.5 \mathrm{~kg} / \mathrm{m}^{2}$ is used in Asian populations [3]. The International Diabetes Federation (IDF) estimated in 2019 that 1 in 11 adults aged 20-79 years (463 million) have diabetes mellitus, with a projected number of more than 700 million cases by 2045 [4]. T2DM accounts for at least $90 \%$ of diabetes mellitus cases $[5,6]$. 
In 1973, the term "diabesity" was first used by Sims et al. to describe the pathophysiological connection between excess weight and T2DM [7]. Diabesity management is challenging because several types of glucose-lowering medications that are used in T2DM, such as sulfonylureas, meglitinides, thiazolidinediones, and insulin (including insulin analogs), could cause weight gain [8]. Increasing physical activity and following a calorie restriction diet are the main pillars for weight reduction [9]. Weight loss of at least $5 \%$ of baseline level in obese patients is clinically significant and improves several obesity-related cardio-metabolical complications, such as arterial hypertension, dyslipidemia, and impaired glucose metabolism (including prediabetes and T2DM) [10-12]. Pharmacological treatment is generally recommended in patients who did not present significant improvement after lifestyle modifications and BMI $\geq 30 \mathrm{~kg} / \mathrm{m}^{2}$ or $\geq 27 \mathrm{~kg} / \mathrm{m}^{2}$, with excess weight-associated comorbidities such as diabesity $[1,13,14]$. Currently approved anti-obesity drugs are illustrated in Table 1.

Table 1. Currently approved anti-obesity pharmacological treatment.

\begin{tabular}{|c|c|c|c|}
\hline Drug Name, Posology & Mechanism of Action & FDA-Approved & EMA-Approved \\
\hline $\begin{array}{c}\text { orlistat, } \\
60-120 \mathrm{mg} 3 \times 1 \text { tablet daily }\end{array}$ & Pancreatic lipase inhibitor & YES (1999) & YES (1998) \\
\hline $\begin{array}{c}\text { phentermine/topiramate, } \\
3.75 / 23 \mathrm{mg} ; 7.5 / 46 \mathrm{mg} ; 11.25 / 69 \mathrm{mg} ; \\
15 / 92 \mathrm{mg} \text { once daily }\end{array}$ & $\begin{array}{l}\text { Sympathomimetic, appetite } \\
\text { suppressant }\end{array}$ & YES (2012) & $\mathrm{NO}$ \\
\hline $\begin{array}{c}\text { naltrexone/bupropion, } \\
32 / 360 \mathrm{mg} 2 \times 4 \text { tablets daily }\end{array}$ & $\begin{array}{l}\text { Opioid receptor } \\
\text { antagonist/dopamine and } \\
\text { noradrenaline reuptake } \\
\text { inhibitor }\end{array}$ & YES (2012) & YES (2015) \\
\hline $\begin{array}{c}\text { liraglutide, } \\
3.0 \mathrm{mg} \text { injection once daily }\end{array}$ & GLP-1 receptor agonist & YES (2014) & YES (2015) \\
\hline $\begin{array}{c}\text { semaglutide, } \\
2.4 \mathrm{mg} \text { injection once weekly }\end{array}$ & GLP-1 receptor agonist & YES (2021) & $\mathrm{NO}$ \\
\hline
\end{tabular}

Abbreviations: mg, milligram; GLP-1: glucagon-like peptide 1; FDA, Food and Drug Administration; EMA, European Medicines Agency.

GLP-1 RAs and sodium-glucose co-transporter type 2 (SGLT-2) inhibitors are usually the class of drugs preferred in managing diabesity in association with metformin due to their association with weight loss $[13,15]$. In the present article, we aim to review and highlight the existing literature on the effects of liraglutide in managing diabesity and excess-weight individuals without diabetes, emphasizing its role as a lower-glucose therapy with benefits on cardiovascular outcomes, weight reduction, and quality of life.

\section{GLP-1 Receptor Agonists}

\subsection{Physiology and Mechanism of Action of GLP-1}

GLP-1 is an endogenous incretin hormone secreted by small intestinal L cells in the distal ileum and proximal colon after ingestion of glucose and other carbohydrates, having low concentrations during fasting. GLP-1 receptors belong to the G-protein coupled receptor family and are mainly expressed in the pancreas, central nervous system, and gastrointestinal tract, also being found in the heart, kidneys, blood vessels, and peripheral nervous system [16]. Once GLP-1 binds to its receptor, the pancreatic beta-cells increase insulin production in a glucose-dependent manner due to enhanced intracellular levels of cyclic adenosine monophosphate (cAMP) [17]. It also promotes the survival and proliferation of pancreatic beta-cells $[18,19]$. Furthermore, GLP-1 inhibits glucagon secretion by pancreatic alfa-cells, reducing hepatic glucose production [20]. Other biological effects of endogenous GLP-1 include slowing gastric emptying, increasing postprandial satiety, and reducing appetite and food consumption by interfering in the central nervous system $[21,22]$. GLP-1 influences the neurons of the paraventricular and arcuate nucleus of the hypothalamus, attenuating orexigenic signals and reducing appetite [23,24]. GLP-1 has 
been shown to have cardioprotective effects associated with a reduction in systolic blood pressure, beneficial effects in ischemic cardiac injury or heart failure, and improvements in dyslipidemia [25-27]. Additionally, from a renal point of view, it induces diuresis and natriuresis [28]. The main biological effects of GLP-1 are summarized in Figure 1 [29].

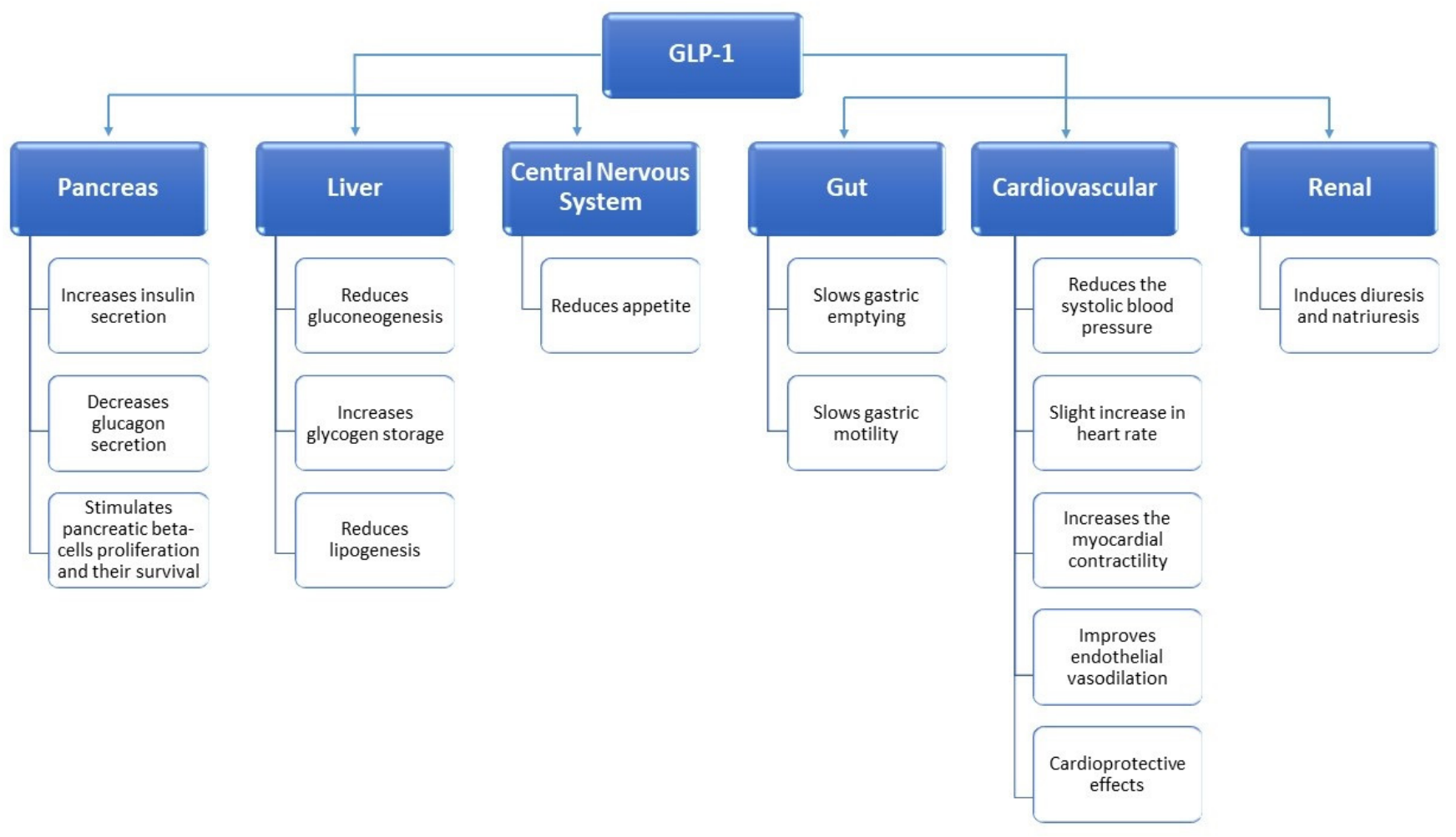

Figure 1. The main biological effects of Glucagon-like peptide 1(GLP-1).

The biological effects are limited by the short half-life of fewer than 2 min due to the rapid degradation of the endogenic GLP-1 by dipeptidyl peptidase IV (DPP4) [30-32].

\subsection{Development, Pharmacokinetics, and Availability of GLP-1 Receptor Agonists}

Given the beneficial effects of GLP-1 on glucose metabolism, its weight-loss potential, and the cardioprotective properties, there was an immense interest in developing pharmacological compounds that could mimic the action of GLP-1 and be resistant to the degradation of DPP-4 in order to be used in T2DM management. The first GLP-1 receptor agonist approved for T2DM treatment was the synthetic exenatide-4, eventually named exenatide, which was developed using the venom of the Gila Monster lizard.

Based on their pharmacological kinetics, GLP-1 receptor agonists are classified as short- or long-acting agents. Short-acting compounds are characterized by periods during which patients are exposed to circulating drug concentration that lasts for a few hours, followed by periods of GLP-1 inactivity. On the contrary, long-acting compounds produce a long-lasting circulating drug concentration with minor drug fluctuations. Given their pharmacokinetics, long-acting GLP-1 agonists have a greater capacity to lower the fasting plasma glucose than short-acting agents. The primary mechanism of glucose-lowering for short-acting GLP-1 Ras is defined by the slowed gastric emptying, while long-acting GLP-1 RAs lower the glucose by increasing insulin production and inhibiting glucagon. Short-acting GLP-1 RAs are exenatide (Byetta) and lixisenatide (Lyxumia, Adlyxin). Longacting GLP-RAs are liraglutide (Victoza, Saxenda), once-weekly exenatide (Bydureon), dulaglutide (Trulicity), albiglutide (Eperzan, Tanzeum), semaglutide (Ozempic), and oral semaglutide (Rybelsus). GLP-1 RAs approved for use in T2DM treatment are summarized in Table 2 [33-35]. 
Table 2. GLP-1 RAs approved for T2DM treatment.

\begin{tabular}{|c|c|c|c|c|}
\hline GLP-1 Agonist & Duration of Action & First Approval & $\begin{array}{l}\text { Elimination } \\
\text { Half-Life }\end{array}$ & Posology \\
\hline Exenatide & Short-acting & $\begin{array}{c}2005 \text { (USA) } \\
2006 \text { (Europe) }\end{array}$ & $3.3-4.0 \mathrm{~h}$ & $\begin{array}{l}\text { Subcutaneous injection, twice } \\
\text { daily, before meals } \\
\text { Dosage: } 5 \mu \mathrm{g} \text {, after } 1 \text { month, } \\
\text { increase to } 10 \mu \mathrm{g}\end{array}$ \\
\hline Lixisenatide & Short-acting & $\begin{array}{c}2013 \text { (Europe) } \\
2016 \text { (USA) }\end{array}$ & $2.6 \mathrm{~h}$ & $\begin{array}{l}\text { Subcutaneous injection, once daily, } \\
\text { before meals } \\
\text { Dosage: } 10 \mu \mathrm{g} \text {, after } 15 \text { days, } \\
\text { increase to } 20 \mu \mathrm{g}\end{array}$ \\
\hline Liraglutide & Long-acting & $\begin{array}{c}2009 \text { (Europe) } \\
2010 \text { (USA) }\end{array}$ & $12.6-14.3 \mathrm{~h}$ & $\begin{array}{l}\text { Subcutaneous injection, once daily } \\
\text { Dosage: } 0.6 \mathrm{mg} \text {, after } 1 \text { week, } \\
\text { increase to } 1.2 \mathrm{mg} \text {; it can be } \\
\text { increased to } 1.8 \mathrm{mg} \text { in case of poor } \\
\text { glycemic control }\end{array}$ \\
\hline $\begin{array}{l}\text { Once-weekly } \\
\text { Exenatide }\end{array}$ & Long-acting & 2012 & $3.3-4.0 \mathrm{~h}$ & $\begin{array}{l}\text { Subcutaneous injection, } \\
\text { once weekly } \\
\text { Dosage: } 2 \text { mg once weekly with or } \\
\text { without meals }\end{array}$ \\
\hline Dulaglutide & Long-acting & 2014 & 4.7-5.5 days & $\begin{array}{l}\text { Subcutaneous injection, once } \\
\text { weekly } \\
\text { Dosage: } 0.75 \mathrm{mg} \text { once weekly; it } \\
\text { can be increased to } 1.5 \mathrm{mg} \text { in case } \\
\text { of poor glycemic control }\end{array}$ \\
\hline Albiglutide & Long-acting & 2014 & 5.7-6.8 days & $\begin{array}{l}\text { Subcutaneous injection, } \\
\text { once weekly } \\
\text { Dosage: } 30 \mathrm{mg} \text { once weekly; it can } \\
\text { be increased to } 50 \mathrm{mg} \text { in case of } \\
\text { poor glycemic control }\end{array}$ \\
\hline Semaglutide & Long-acting & $\begin{array}{c}2017 \text { (USA) } \\
2018 \text { (Europe) }\end{array}$ & 5.7-6.7 days & $\begin{array}{l}\text { Subcutaneous injection, once } \\
\text { weekly } \\
\text { Dosage: } 0.25 \mathrm{mg} \text { once weekly, after } \\
1 \text { month, increase to } 0.5 \mathrm{mg} \text {; it can } \\
\text { be increased to } 1 \mathrm{mg} \text { in case of } \\
\text { poor glycemic control }\end{array}$ \\
\hline Semaglutide & Long-acting & 2019 & 5.7-6.7 days & $\begin{array}{l}\text { Oral administration, once weekly, } \\
\text { before meals } \\
\text { Dosage: } 3 \mathrm{mg} \text {, after } 1 \mathrm{month}, \\
\text { increase to } 7 \mathrm{mg} \text {; it can be } \\
\text { increased to } 14 \mathrm{mg} \text { in case of poor } \\
\text { glycemic control }\end{array}$ \\
\hline
\end{tabular}

GLP-1 RAs: glucagon-like peptide 1 receptor agonists; T2DM: type 2 diabetes mellitus.

\section{Liraglutide in Diabesity Management}

Liraglutide's (Victoza) safety and efficacy were assessed in the Liraglutide Effect and Action in Diabetes (LEAD) program, including 6 phase III randomized clinical trials. Liraglutide was studied in this program alone or in combination therapy with other antidiabetic drugs.

\subsection{Liraglutide in Blood Glucose Control}

LEAD-1 included 1041 subjects with T2DM and compared the combination of liraglutide $0.6,1.2$, and $1.8 \mathrm{mg} /$ day, or rosiglitazone $4 \mathrm{mg}$ /day or placebo, with glimepiride for 26 weeks. When added to glimepiride, liraglutide ( $1.2 \mathrm{or} 1.8 \mathrm{mg} /$ day) had a greater reduction in glycated hemoglobin $(\mathrm{HbA1c})$ when compared to placebo $(p \leq 0.0001)$ or to 
rosiglitazone $(p \leq 0.0001)$. Postprandial glucose was significantly improved with liraglutide 1.2 or $1.8 \mathrm{mg}$ compared to placebo $(p \leq 0.0001)$ or to rosiglitazone $(p \leq 0.05)$ [36].

In the LEAD-2 trial, which included 1091 subjects, liraglutide was compared with placebo and glimepiride $4 \mathrm{mg}$ /day. All treatments were administered in combination with metformin $2000 \mathrm{mg}$ /day. Liraglutide-treated subjects were superior to placebo and non-inferior to glimepiride when referring to glycemic control [37]. Liraglutide was also compared with insulin glargine and placebo during the LEAD-5 trial, including 581 subjects with T2DM with prior monotherapy and combination therapy. Liraglutide $1.8 \mathrm{mg} /$ day had a greater reduction in $\mathrm{HbA1}$ c compared to insulin glargine at 26 weeks $(-1.33 \%$ vs. $-1.09 \%, p=0.0015)$, with similar reductions in FBG and postprandial glucose [38] A comparison between liraglutide $1.8 \mathrm{mg}$ and twice-daily $10 \mu \mathrm{g}$ exenatide was conducted in the LEAD-6 study in adults with uncontrolled T2DM on maximum doses of metformin and sulfonylurea. Liraglutide reduced mean $\mathrm{HbA} 1 \mathrm{c}$ significantly more than exenatide $(-1.12 \%$ vs. $-0.79 \%$; estimated treatment difference (ETD) $-0.33 \%, p \leq 0.0001)$. FBG was reduced more in liraglutide-treated subjects than exenatide $(-1.61 \mathrm{mmol} / \mathrm{L}$ vs. $-0.60 \mathrm{mmol} / \mathrm{L}$; ETD $-1.01 \mathrm{mmol} / \mathrm{L}, p \leq 0.0001)$. More patients with liraglutide achieved $\mathrm{HbA} 1 \mathrm{c}<7 \%$ compared with exenatide (54\% vs. $43 \% ; p=0.0015)$ [39].

\subsection{Liraglutide in Body Weight Management}

Liraglutide can activate GLP-1 receptors found in hypothalamic regions that control feeding, such as the hypothalamic paraventricular and arcuate nucleus. For example, in the arcuate nucleus, liraglutide stimulates the appetite-inhibiting pro-opiomelanocortin neurons and inhibits the orexigenic neuropeptide- $Y$ and Agouti-related peptide neurons, resulting in reduced food intake and increased satiety [40].

Liraglutide has proven its weight loss benefits in several clinical trials. In the LEAD-2 trial, body weight loss in a dose-dependent manner was noted in the liraglutide group (up to $2.8 \mathrm{~kg}$ ) compared to the glimepiride group, that had associated weight gain [37]. In the LEAD-5 trial, liraglutide produced significant weight loss vs. placebo (treatment difference $-1.39 \mathrm{~kg}, p=0.0001$ ) and vs. insulin glargine (treatment difference $-3.43 \mathrm{~kg}$, $p=0.0001$ ) [38]. In the LEAD-6 trial, liraglutide $1.8 \mathrm{mg} /$ day and exenatide $10 \mu \mathrm{g}$ twice-daily produced similar weight loss outcomes $(-3.24 \mathrm{~kg}$ vs. $-2.87, p=0.22)$ [39].

The Satiety and Clinical Adiposity-Liraglutide Evidence (SCALE) clinical trial conducted at 126 sites in 9 countries investigated the safety and efficacy of liraglutide as a weight-reducing drug in excess-weight individuals with T2DM, in association with a $500 \mathrm{kcal} /$ day deficit and increased physical activity. After 56 weeks, in subjects with T2DM, $3.0 \mathrm{mg}$ of daily liraglutide was associated with the most weight loss when compared to liraglutide $1.8 \mathrm{mg} /$ day and placebo $(6.4 \mathrm{~kg}$ vs. $5.0 \mathrm{~kg}$ vs. $2.2 \mathrm{~kg}$; ETD for liraglutide 3.0 vs. placebo- $4.00 \%$; ETD for liraglutide 1.8 vs. placebo $-2.71 \%$; $p$ for both liraglutide $\leq 0.001$ ) [41]. Weight loss of $5-10 \%$ of body weight is associated with improved glycemic control and improved outcome of comorbidities in T2DM. Weight loss of at least $5 \%$ occurred in $54.3 \%$ with liraglutide $3.0 \mathrm{mg}, 40.4 \%$ with liraglutide $1.8 \mathrm{mg}$, and $21.4 \%$ with placebo ( $p$ for both liraglutide $\leq 0.001$ ). Furthermore, a reduction of at least $10 \%$ in weight loss was noted in $25.2 \%$ of cases with liraglutide $3.0 \mathrm{mg}, 15.9 \%$ with liraglutide $1.8 \mathrm{mg}$, and $6.7 \%$ with placebo (ETD between liraglutide $3.0 \mathrm{mg}$ vs. placebo, $p \leq 0.001$; for liraglutide $1.8 \mathrm{mg}$ vs. placebo, $p=0.006$ ) [41].

The SCALE Obesity and Prediabetes double-blinded trial investigated the possible benefits of liraglutide $3.0 \mathrm{mg}$ /day for 56 weeks in 3731 individuals without T2DM with a BMI higher than 30 or $27 \mathrm{~kg} / \mathrm{m}^{2}$ when dyslipidemia or hypertension are present. At week 56 , liraglutide-treated subjects achieved a weight loss of $8.4 \pm 7.3 \mathrm{~kg}$ vs. placebo group with a loss of $2.8 \pm 6.5 \mathrm{~kg}$ (ETD $-5.6 \mathrm{~kg}, p \leq 0.001)$. Furthermore, $63.2 \%$ of subjects in the liraglutide group had a weight loss of at least $5 \%$ from baseline vs. $27.1 \%$ of subjects in the placebo group $(p \leq 0.001)$. A weight loss of at least $10 \%$ was encountered in $33.1 \%$ in the liraglutide group vs. $10.6 \%$ in the placebo group $(p \leq 0.001)$ [42]. 
Based on the SCALE clinical trial results, liraglutide alongside lifestyle changes has beneficial effects not only in T2DM but also in patients without diabetes by promoting weight loss and improving metabolic control, meaning it can prevent the development of T2DM in this category of patients. Therefore, given its positive outcomes on weight loss, liraglutide $3.0 \mathrm{mg}$ was approved by both the Food and Drugs Administration (FDA) (2014) and European Medicines Agency (EMA) (2015) as an anti-obesity drug in patients without diabetes sold under the name of Saxenda, making it the first GLP-1 RA approved for use in chronic weight management. Recently, the FDA approved the use of Semaglutide $2.4 \mathrm{mg}$ /once weekly (June 2021) as a chronic weight management drug in adults with obesity or overweight with at least one weight-related condition after proving its weight benefits in several clinical trials [43-46].

Liraglutide also shows very promising perspectives in the pharmacological management of obesity in individuals under 18 years of age. In 2020, a randomized double-blinded trial, which investigated the use of liraglutide $3.0 \mathrm{mg}$ as a weight reduction option in obese adolescents, published its results. Liraglutide was found to be superior to placebo plus lifestyle therapy in reducing the BMI standard deviation score at week 56 (ETD - $0.22 \%$; $95 \%$ confidence interval (CI) -0.37 to $-0.08 ; p=0.002$ ) [47]. A randomized, placebocontrolled trial aimed to investigate the maintenance of weight loss achieved through caloric deficit followed by a 1-year treatment with liraglutide, physical activity, or both, compared with placebo in individuals with obesity. In the recently published results, liraglutide $3.0 \mathrm{mg} /$ day when combined with physical activity greatly improved weight loss maintenance compared with liraglutide alone or physical exercise alone $(-9.5 \mathrm{~kg}$ vs. $-6.8 \mathrm{~kg}$ vs. $-4.1 \mathrm{~kg}$ ) [48]. These results strengthen the weight loss benefits of liraglutide and emphasize the critical role of physical activity in chronic weight management.

\subsection{Liraglutide and Cardiovascular Outcomes}

In the LEAD-5 clinical trial, liraglutide had a beneficial effect on systolic blood pressure vs. insulin glargine $(-4.5 \mathrm{mmHg}$ difference, $p=0.0001)$, although not when compared to placebo ( $p=0.0791)$ [38]. The cardiovascular outcomes of liraglutide were investigated in the LEADER trial (Liraglutide Effect and Action in Diabetes: Evaluation of cardiovascular outcome Results): 9340 subjects with T2DM and high cardiovascular risk were randomized and followed for a median of 3.8 years. The LEADER trial noted that primary outcomes (cardiovascular death, nonfatal myocardial infarction, or nonfatal stroke) occurred less in the liraglutide group (608 out of $4668(13.0 \%)$ ) vs. placebo (694 out of $4672(14.9 \%)$ ) (hazard ratio (HR) $0.87 ; 95 \%$ CI $0.78-0.97 ; p=<0.001$ for non-inferiority; $p=0.01$ for superiority). Furthermore, death from cardiovascular causes occurred less frequently in the liraglutide group vs. placebo (4.7\% vs. $6.0 \% ; p=0.007)$. All-cause mortality was reduced in the liraglutide group vs. placebo $(8.2 \%$ vs. $9.6 \% ; p=0.02)$. Nonfatal myocardial infarction and nonfatal stroke were less frequent in the liraglutide group than in the placebo group; however, the difference was not significant. Moreover, heart failure hospitalization rates were lower in the liraglutide group but without a significant difference vs. the placebo group [49]. Aiming to evaluate the effects of liraglutide on cardiovascular events and mortality based on patients' heart failure history, T2DM participants in the LEADER trial were assigned through randomization to placebo or liraglutide $(1.8 \mathrm{mg}$ daily or a maximum tolerated dose up to $1.8 \mathrm{mg}$ daily). The risk of heart failure hospitalization was not increased in the liraglutide group vs. placebo, regardless of heart failure history at baseline. Moreover, use of liraglutide when compared to placebo was associated with lower rates of major cardiovascular events, nephropathy, and mortality, and therefore, liraglutide should be considered appropriate for use in patients with diabetes with or without a history of heart failure (New York Heart Association functional class I to III) [50].

In a post hoc analysis of the LEADER trial 1, the cardiovascular effects of liraglutide vs. placebo in patients with or without preexisting metformin treatment were analyzed. It was noted that the incidence of primary outcomes (time from randomization to first occurrence of cardiovascular death, myocardial infarction, or stroke) was not significantly 
reduced in liraglutide users when compared to placebo among previous metformin users (HR adjusted 0.97; 95\% CI: 0.85-1.10), but liraglutide did reduce the incidence among metformin non-users (HR adjusted $0.79 ; 95 \%$ CI: $0.64-0.97$ ), highlighting a possible role that metformin could have in enhancing the cardiovascular benefits of GLP-1 RAs [51].

A systematic review and meta-analysis which included 8 studies published between 2009 and 2016 and a total of 14,608 patients with T2DM showed that patients who underwent liraglutide treatment had a lower risk compared to comparison groups of developing major cardiovascular events (MACE), acute myocardial infarction, and cardiovascular death, but not a decreased incidence of stroke. However, regarding MACE, a significant decreased incidence with liraglutide was noticed only in trials using placebo (relative risk $(\mathrm{RR})=0.89,95 \% \mathrm{CI}$ : $0.83-0.96, p=0.004)$ and not in those using other comparators $(\mathrm{RR}=0.58,95 \%$ CI: $0.29-1.16, p=0.122)$ [52].

A register-based study performed in Denmark and Sweden analyzed the risk of major cardiovascular events between patients with T2DM treated with liraglutide and dipeptidyl peptidase-4 (DPP-4) inhibitors. Liraglutide had a significantly lower risk of cardiovascular death compared with DPP-4 inhibitors (HR: 0.78, 95\% CI: 0.68-0.91) and a significantly lower risk of death from any cause (HR: $0.83,95 \%$ CI: 0.77-0.90). However, no significant differences were observed for risk of myocardial infarction (HR: 0.94, 95\% CI: 0.84-1.06), stroke (HR: 0.88, 95\% CI: 0.77-1.01), risk of heart failure (HR: 0.90, 95\% CI: 0.80-1.03), or for other major cardiovascular event outcomes (HR: 0.95, 95\% CI: 0.89-1.01) [53].

A post hoc analysis using data from 5908 participants with obesity in 5 SCALE randomized controlled trials (liraglutide vs. placebo or orlistat) revealed that liraglutide $3 \mathrm{mg}$ was not associated with an increased risk of cardiovascular events (HR: 0.42; 95\% CI: 0.17-1.08) [54].

A summary of the presented clinical trials and their primary outcomes is illustrated in Supplementary Table S1.

\section{Liraglutide Side Effects}

\subsection{Gastrointestinal Side Effects and Concerns}

Liraglutide side effects are shared with other GLP-1 RAs. The most common side effects reported with GLP-1 RAs treatment are gastrointestinal areal, nausea, vomiting, and diarrhea, being the most frequent signs and symptoms reported. Most commonly, these side effects occur after the initiation of the pharmacological treatment and after increasing the dose. Therefore, to minimize the impact of these adverse events, it is recommended that every GLP-1 RA be initiated at a lower dose, then slowly increase the dose through up-titration regimens.

The mild elevation in amylase and/or lipase, together with the abdominal discomfort, both situations commonly found in GLP-1 RA-treated individuals, led to the concerns of pancreatitis [55]. Liraglutide $1.8 \mathrm{mg}$ showed a $28 \%$ increase in lipase levels and a $7 \%$ increase in amylase levels compared to placebo, while liraglutide $3.0 \mathrm{mg}$ had a $30 \%$ increase in lipase levels and a 7\% increase in amylase levels [56]. A meta-analysis from 2017 confirmed the safety of GLP-1 RAs for pancreatitis, reporting that the incidence of pancreatitis and pancreatic cancer was not significantly different between GLP-1 RAs and comparators (odds ratio (OR) $0.93 ; 95 \%$ CI $0.65-1.34 ; p=0.71$, and odds ratio 0.94 ; 95\% CI 0.52-1.70; $p=0.84$ ) [57].

Interestingly, a meta-analysis from 2018 documented the possibility of protective properties of incretin drugs against pancreatic cancer in T2DM patients who followed incretin-based antidiabetic treatment $\geq 104$ weeks (OR 0.62; 95\% CI 0.41-0.95) [58]. A recent meta-analysis based on cardiovascular outcomes trials found no significant risk of acute pancreatitis nor for any malignant neoplasms [59]. Nevertheless, it is recommended to avoid GLP-1 RAs in patients with pancreatic cancer or pancreatitis [60]. A recent meta-analysis pointed out a significant risk of cholelithiasis in liraglutide-treated patients $(0.6-3.0 \mathrm{mg})[61]$. 


\subsection{Hypoglycemia}

Liraglutide is associated with a low risk of hypoglycemia. GLP-1 RAs increase insulin secretion and inhibit the glucagon action in a glucose-dependent manner, making it less likely for hypoglycemia [62]. Nevertheless, the use of liraglutide in combination with insulin or sulfonylureas may increase the hypoglycemia risk [36-38].

\subsection{Medullary Thyroid Cancer Concerns}

There were concerns about a possible increased risk of developing medullary thyroid carcinoma (MTC) after an association was noted in rodent studies between long-acting GLP-1 RA (such as liraglutide) and thyroid parafollicular C-cell hyperplasia. However, in humans, these concerns have not been confirmed so far as no such association between liraglutide and MTC has been detected in any clinical trials to date. One explanation for the association between MTC and liraglutide seen in rodents and not in humans could be that rodents' parafollicular C-cells have more GLP-1 receptors [63]. Nevertheless, GLP-1 RAs are not recommended in subjects at high risk of developing MTC, such as a known personal or family history of MTC and/or multiple endocrine neoplasia type 2A and 2B [33,60].

\subsection{Kidney Function}

Investigating the kidney function before initiating treatment with GLP-1 RAs is highly important, by measuring the creatinine levels and the estimated glomerular filtration rate (eGFR). Liraglutide is safe to use in moderate renal impairment (eGFR: $30-60 \mathrm{~mL} / \mathrm{min} / 1.73 \mathrm{~m}^{2}$ ), while in severe (eGFR: $15-30 \mathrm{~mL} / \mathrm{min} / 1.73 \mathrm{~m}^{2}$ ) and end-stage renal disease (eGFR: $<15 \mathrm{~mL} / \mathrm{min} / 1.73 \mathrm{~m}^{2}$ ), it should be used with caution due to limited data [64]. There have been reports of acute kidney injury in chronic kidney disease individuals following treatment with GLP-1 RAs. The use of diuretics or renin-angiotensin-aldosterone system inhibitors in the presence of vomiting and established chronic kidney disease could potentially complicate the GLP-1 RAs treatment [60].

\section{Conclusions}

Diabetes mellitus and obesity are two metabolic disorders whose prevalence have significantly increased over the past decades and are often coexisting. Liraglutide is an efficient and safe option in diabesity treatment, proving in several studies its safety and efficacy as a glucose-lowering agent and a weight reduction drug in individuals with and without diabetes. Having relatively low contraindications and cardiovascular benefits, liraglutide is a modern option in fighting the diabesity pandemic.

Supplementary Materials: The following are available online at https: / www.mdpi.com/article/10 .3390 / medicina57070669/s1, Table S1: Main outcomes of LEAD, SCALE, and LEADER clinical trials.

Author Contributions: Conceptualization, M.C.T. and R.A.T.; methodology, R.A.T. and A.B.; validation, M.C.T., A.B.; writing-original draft preparation, R.A.T., A.V.; writing—review and editing, A.B.; supervision, M.C.T., A.B. All authors have read and agreed to the published version of the manuscript.

Funding: This research received no external funding.

Institutional Review Board Statement: Not Applicable.

Informed Consent Statement: Not applicable.

Conflicts of Interest: The authors declare no conflict of interest.

\section{References}

1. Hasanzad, M.; Sarhangi, N.; Nikfar, S.; Ostad, S.N.; Aghaei Meybodi, H.R. A narrative review of current trends in liraglutide: Insights into the unmet needs in management of type 2 diabetes and obesity. J. Diabetes Metab. Disord. 2020, 19, $1863-1872$. [CrossRef] [PubMed]

2. World Health Organization (WHO). Obesity and Overweight. 2020. Available online: https://www.who.int/news-room/factsheets/detail/obesity-and-overweight (accessed on 12 March 2021). 
3. Purnell, J.Q. Definitions, Classification, and Epidemiology of Obesity. In Endotext [Internet]; Feingold, K.R., Anawalt, B., Boyce, A., Chrousos, G., de Herder, W.W., Dhatariya, K., Dungan, K., Grossman, A., Hershman, J.M., Hofland, J., et al., Eds.; [Updated 12 April 2018]; MDText.com, Inc.: South Dartmouth, MA, USA, 2018. Available online: https://www.ncbi.nlm.nih.gov/books/ NBK279167/ (accessed on 12 March 2021).

4. International Diabetes Federation. IDF Diabetes Atlas-9th Edition. DiabetesAtlas. Available online: http://www.diabetesatlas. org / (2019) (accessed on 12 March 2021).

5. Zheng, Y.; Ley, S.H.; Hu, F.B. Global aetiology and epidemiology of type 2 diabetes mellitus and its complications. Nat. Rev. Endocrinol. 2018, 14, 88-98. [CrossRef] [PubMed]

6. Boles, A.; Kandimalla, R.; Reddy, P.H. Dynamics of diabetes and obesity: Epidemiological perspective. Biochim. Biophys. Acta Mol. Basis Dis. 2017, 1863, 1026-1036. [CrossRef]

7. Sims, E.A.; Danforth, E., Jr.; Horton, E.S.; Bray, G.A.; Glennon, J.A.; Salans, L.B. Endocrine and metabolic effects of experimental obesity in man. Recent Prog. Horm. Res. 1973, 29, 457-496. [PubMed]

8. Apovian, C.M.; Okemah, J. O'Neil PM, Body Weight Considerations in the Management of Type 2 Diabetes. Adv. Ther. 2019, 36, 44-58. [CrossRef]

9. Canuto, R.; Garcez, A.; de Souza, R.V.; Kac, G.; Olinto, M.T.A. Nutritional intervention strategies for the management of overweight and obesity in primary health care: A systematic review with meta-analysis. Obes. Rev. 2021, 22, e13143. [CrossRef]

10. Look, A.R.; Wing, R.R. Long-term effects of a lifestyle intervention on weight and cardiovascular risk factors in individuals with type 2 diabetes mellitus: Four-year results of the Look AHEAD trial. ArchIntern. Med. 2010, 170, 1566-1575.

11. Seo, M.H.; Lee, W.Y.; Kim, S.S.; Kang, J.H.; Kang, J.H.; Kim, K.K.; Kim, B.Y.; Kim, Y.H.; Kim, W.J.; Kim, E.M.; et al. 2018 Korean Society for the Study of Obesity Guideline for the Management of Obesity in Korea. J. Obes. Metab. Syndr. 2019, 28, 40-45, Erratum in J. Obes. Metab. Syndr. 2019, 28, 143. [CrossRef] [PubMed]

12. Tak, Y.J.; Lee, S.Y. Long-Term Efficacy and Safety of Anti-Obesity Treatment: Where Do We Stand? Curr. Obes. Rep. 2021, 10, 14-30. [CrossRef] [PubMed]

13. American Diabetes Association. Obesity management for the treatment of type 2 diabetes: Standards of Medical Care in Diabetes-2021. Diabetes Care 2021, 44, S100-S110. [CrossRef]

14. Williams, D.M.; Nawaz, A.; Evans, M. Drug Therapy in Obesity: A Review of Current and Emerging Treatments. Diabetes Ther. 2020, 11, 1199-1216. [CrossRef]

15. American Diabetes Association. 9. Pharmacologic approaches to glycemic treatment: Standards of Medical Care in Diabetes2021. Diabetes Care 2021, 44, S111-S124. [CrossRef]

16. Müller, T.D.; Finan, B.; Bloom, S.R.; D’Alessio, D.; Drucker, D.J.; Flatt, P.R.; Fritsche, A.; Gribble, F.; Grill, H.J.; Habener, J.F.; et al. Glucagon-like peptide 1 (GLP-1). Mol. Metab. 2019, 30, 72-130. [CrossRef]

17. Holst, J.J. The physiology of glucagon-like peptide 1. Physiol. Rev. 2007, 87, 1409-1439. [CrossRef]

18. Farilla, L.; Bulotta, A.; Hirshberg, B.; Li Calzi, S.; Khoury, N.; Noushmehr, H.; Bertolotto, C.; Di Mario, U.; Harlan, D.M.; Perfetti, R. Glucagon-like peptide 1 inhibits cell apoptosis and improves glucose responsiveness of freshly isolated human islets. Endocrinology 2003, 144, 5149-5158. [CrossRef]

19. Drucker, D.J. Glucagon-like peptide-1 and the islet beta-cell: Augmentation of cell proliferation and inhibition of apoptosis. Endocrinology 2003, 144, 5145-5148. [CrossRef]

20. Campbell, J.E.; Drucker, D.J. Pharmacology, physiology, and mechanisms of incretin hormone action. Cell Metab. 2013, $17,819-837$. [CrossRef]

21. Holst, J.J. Incretin hormones and the satiation signal. Int. J. Obes. 2013, 37, 1161-1168. [CrossRef] [PubMed]

22. Velazquez, A.; Apovian, C.M. Updates on obesity pharmacotherapy. Ann. N. Y. Acad. Sci. 2018, 1411, 106-119. [CrossRef] [PubMed]

23. Tang-Christensen, M.; Vrang, N.; Larsen, P.J. Glucagon-like peptide containing pathways in the regulation of feeding behaviour. Int. J. Obes. Relat. Metab. Disord. 2001, 25, S42-S47. [CrossRef] [PubMed]

24. Tang-Christensen, M.; Vrang, N.; Larsen, P.J. Glucagon-like peptide1(7-36) amide's central inhibition of feeding and peripheral inhibition of drinking are abolished by neonatal monosodium glutamate treatment. Diabetes 1998, 47, 530-537. [CrossRef]

25. Chilton, R.; Wyatt, J.; Nandish, S.; Oliveros, R.; Lujan, M. Cardiovascular comorbidities of type 2 diabetes mellitus: Defining the potential of glucagonlike peptide-1-based therapies. Am. J. Med. 2011, 124, S35-S53. [CrossRef]

26. Nikolaidis, L.A.; Sunil, M.; George GSokos, G.M.; Ankur, S.; Dariush, E.; Shannon, R.P. Effects of glucagon-like peptide-1 in patients with acute myocardial infarction and left ventricular dysfunction after successful reperfusion. Circulation 2004, 109, 962-965. [CrossRef] [PubMed]

27. Meier, J.J.; Gethmann, A.; Götze, O.; Gallwitz, B.; Holst, J.J.; Schmidt, W.E.; Nauck, M.A. Glucagon-like peptide 1 abolishes the postprandial rise in triglyceride concentrations and lowers levels of non-esterified fatty acids in humans. Diabetologia 2006, 49, 452-458. [CrossRef] [PubMed]

28. Gutzwiller, J.P.; Tschopp, S.; Bock, A.; Zehnder, C.E.; Huber, A.R.; Kreyenbuehl, M.; Gutmann, H.; Drewe, J.; Henzen, C.; Goeke, B.; et al. Glucagon-like peptide 1 induces natriuresis in healthy subjects and in insulin-resistant obese men. J. Clin. Endocrinol. Metab. 2004, 89, 3055-3061. [CrossRef] [PubMed]

29. Brown, E.; Cuthbertson, D.J.; Wilding, J.P. Newer GLP-1 receptor agonists and obesity-diabetes. Peptides 2018, 100, 61-67. [CrossRef] [PubMed] 
30. Deacon, C.F.; Nauck, M.A.; Toft-Nielsen, M.; Pridal, L.; Willms, B.; Host, J.J. Both subcutaneously and intravenously administered glucagon-like peptide 1 are rapidly degraded from the NH2-terminus in type 2-diabetic patients and in healthy subjects. Diabetes 1995, 44, e1131. [CrossRef]

31. Lee, Y.S.; Jun, H.S. Antidiabetic actions of glucagon-like peptide-1 on pancreatic beta-cells. Metabolism 2014, 63, 9-19. [CrossRef]

32. Nolen-Doerr, E.; Stockman, M.C.; Rizo, I. Mechanism of Glucagon-Like Peptide 1 Improvements in Type 2 Diabetes Mellitus and Obesity. Curr. Obes. Rep. 2019, 8, 284-291. [CrossRef] [PubMed]

33. Nauck, M.A.; Quast, D.R.; Wefers, J.; Meier, J.J. GLP-1 receptor agonists in the treatment of type 2 diabetes-state-of-the-art. Mol. Metab. 2021, 46, 101102. [CrossRef] [PubMed]

34. Gomez-Peralta, F.; Abreu, C. Profile of semaglutide in the management of type 2 diabetes: Design, development, and place in therapy. Drug Des. Devel. Ther. 2019, 13, 731-738. [CrossRef] [PubMed]

35. Brunton, S.; Mosenzon, O.; Wright, E., Jr. Integrating oral semaglutide into clinical practice in primary care: For whom, when, and how? Postgrad. Med. 2020, 132, 48-60. [CrossRef] [PubMed]

36. Marre, M.; Shaw, J.; Brändle, M.; Bebakar, W.M.W.; Kamaruddin, N.A.; Strand, J.; Zdravkovic, M.; Le Thi, T.D.; Colagiuri, S. St on behalf of the LEAD-1 SU study group Liraglutide, a once-daily human GLP-1 analogue, added to a sulphonylurea over 26 weeks produces greater improvements in glycaemic and weight control compared with adding rosiglitazone or placebo in subjects with Type 2 diabetes (LEAD-1 SU). Diabet Med. 2009, 26, 268-278. [PubMed]

37. Nauck, M.; Frid, A.; Hermansen, K.; Shah, N.S.; Tankova, T.; Mitha, I.H.; Zdravkovic, M.; Düring, M.; Matthews, D.R. For the LEAD-2 Study Group Efficacy and safety comparison of liraglutide, glimepiride, and placebo, all in combination with metformin, in type 2 diabetes: The LEAD (liraglutide effect and action in diabetes)-2 study. Diabetes Care 2009, 32, 84-90. [CrossRef] [PubMed]

38. Russell-Jones, D.; Vaag, A.A.; Schmitz, O.; Sethi, B.K.; Lalic, N.; Antić, S.; Zdravkovic, M.; Ravn, G.M.; Simo, R. On behalf of the Liraglutide Effect and Action in Diabetes 5 (LEAD-5) met+SU Study Group Liraglutide vs. insulin glargine and placebo in combination with metformin and sulfonylurea therapy in type 2 diabetes mellitus (LEAD-5 met $+\mathrm{SU}$ ): A randomised controlled trial. Diabetologia 2009, 52, 2046-2055.

39. Buse, J.B.; Rosenstock, J.; Sesti, G.; Schmidt, W.E.; Montanya, E.; Brett, J.H.; Zychma, M.; Blonde, L.; LEAD-6 Study Group. Liraglutide once a day versus exenatide twice a day for type 2 diabetes: A 26-week randomised, parallel-group, multinational, open-label trial (LEAD-6). Lancet 2009, 374, 39-47. [CrossRef]

40. Secher, A.; Jelsing, J.; Baquero, A.F.; Hecksher-Sørensen, J.; Cowley, M.; Dalbøge, L.S.; Hansen, G.; Grove, K.L.; Pyke, C.; Raun, K.; et al. The arcuate nucleus mediates GLP-1 receptor agonist liraglutide-dependent weight loss. J. Clin. Investig. 2014, 124, 4473-4488. [CrossRef] [PubMed]

41. Davies, M.J.; Bergenstal, R.; Bode, B.; Kushner, R.F.; Lewin, A.; Skjøth, T.V.; Andreasen, A.H.; Jensen, C.B.; DeFronzo, R.A.; NN8022-1922 Study Group. Efficacy of Liraglutide for Weight Loss Among Patients With Type 2 Diabetes: The SCALE Diabetes Randomized Clinical Trial. JAMA 2015, 314, 687-699, Erratum in JAMA 2016, 315, 90. [CrossRef]

42. Pi-Sunyer, X.; Astrup, A.; Fujioka, K.; Greenway, F.; Halpern, A.; Krempf, M.; Lau, D.C.W.; le Roux, D.C.W.; Ortiz, R.V.; Jensen, C.B.; et al. A Randomized, Controlled Trial of $3.0 \mathrm{mg}$ of Liraglutide in Weight Management. N. Engl. J. Med. 2015, 373, 11-22. [CrossRef]

43. FDA Approves New Drug Treatment for Chronic Weight Management, First Since 2014. U.S. Food and Drug Administration. Available online: https://www.fda.gov/news-events/press-announcements/fda-approves-new-drug-treatment-chronicweight-management-first-2014.Published2021 (accessed on 9 June 2021).

44. Christou, G.A.; Katsiki, N.; Blundell, J.; Fruhbeck, G.; Kiortsis, D.N. Semaglutide as a promising anti-obesity drug. Obes. Rev. 2019, 20, 805-815. [CrossRef]

45. Kushner, R.F.; Calanna, S.; Davies, M.; Dicker, D.; Garvey, W.T.; Goldman, B.; Lingvay, I.; Thomsen, M.; Wadden, T.A.; Wharton, S.; et al. Semaglutide $2.4 \mathrm{mg}$ for the Treatment of Obesity: Key Elements of the STEP Trials 1 to 5. Obesity 2020, 28, 1050-1061. [CrossRef]

46. Wilding, J.P.; Batterham, R.L.; Calanna, S.; Davies, M.; Van Gaal, L.F.; Lingvay, I.; McGowan, B.M.; Rosenstock, J.; Tran, M.T.; Wadden, T.A.; et al. Once-Weekly Semaglutide in Adults with Overweight or Obesity. N. Engl. J. Med. 2021, 384, 989. [CrossRef]

47. Kelly, A.S.; Auerbach, P.; Barrientos-Perez, M.; Gies, I.; Hale, P.M.; Marcus, C.; Mastrandrea, L.D.; Prabhu, N.; Arslanian, S. A Randomized, Controlled Trial of Liraglutide for Adolescents with Obesity. N. Engl. J. Med. 2020, 382, 2117-2128. [CrossRef] [PubMed]

48. Lundgren, J.R.; Janus, C.; Jensen, S.B.; Juhl, C.R.; Olsen, L.M.; Christensen, R.M.; Svane, M.S.; Bandholm, T.; Bojsen-Møller, K.N.; Blond, M.B.; et al. Healthy Weight Loss Maintenance with Exercise, Liraglutide, or Both Combined. N. Engl. J. Med. 2021, 384, 1719-1730. [CrossRef]

49. Marso, S.P.; Daniels, G.H.; Brown-Frandsen, K.; Kristensen, P.; Mann, J.F.; Nauck, M.A.; Nissen, S.E.; Pocock, S.; Poulter, N.R.; Ravn, L.S.; et al. Liraglutide and Cardiovascular Outcomes in Type 2 Diabetes. N. Engl. J. Med. 2016, 375, 311-322. [CrossRef]

50. Marso, S.P.; Baeres, F.M.; Bain, S.C.; Goldman, B.; Husain, M.; Nauck, M.A.; Poulter, N.R.; Pratley, R.E.; Thomsen, A.B.; Buse, J.B. Effects of Liraglutide on Cardiovascular Outcomes in Patients with Diabetes With or Without Heart Failure. J. Am. Coll. Cardiol. 2020, 75, 1128-1141. [CrossRef] [PubMed]

51. Crowley, M.J.; McGuire, D.K.; Alexopoulos, A.S.; Jensen, T.J.; Rasmussen, S.; Saevereid, H.A.; Verma, S.; Buse, J.B. Effects of Liraglutide on Cardiovascular Outcomes in Type 2 Diabetes Patients With and Without Baseline Metformin Use: Post Hoc Analyses of the LEADER Trial. Diabetes Care 2020, 43, e108-e110. [CrossRef] [PubMed] 
52. Duan, C.M.; Wan, T.F.; Wang, Y.; Yang, Q.W. Cardiovascular outcomes of liraglutide in patients with type 2 diabetes: A systematic review and meta-analysis. Medicine 2019, 98, e17860. [CrossRef] [PubMed]

53. Svanström, H.; Ueda, P.; Melbye, M.; Eliasson, B.; Svensson, A.M.; Franzén, S.; Gudbjörnsdottir, S.; Hveem, K.; Jonasson, C.; Pasternak, B. Use of liraglutide and risk of major cardiovascular events: A register-based cohort study in Denmark and Sweden. Lancet Diabetes Endocrinol. 2019, 7, 106-114. [CrossRef]

54. Davies, M.J.; Aronne, L.J.; Caterson, I.D.; Thomsen, A.B.; Jacobsen, P.B.; Marso, S.P. Satiety and Clinical Adiposity-Liraglutide Evidence in individuals with and without diabetes (SCALE) study groups. Liraglutide and cardiovascular outcomes in adults with overweight or obesity: A post hoc analysis from SCALE randomized controlled trials. Diabetes Obes. Metab. 2018, 20, 734-739. [CrossRef]

55. Lando, H.M.; Alattar, M.; Dua, A.P. Elevated amylase and lipase levels in patients using glucagonlike peptide- 1 receptor agonists or dipeptidyl-peptidase-4 inhibitors in the outpatient setting. Endocr. Pract. 2012, 18, 472-477. [CrossRef]

56. Seo, Y.G. Side Effects Associated with Liraglutide Treatment for Obesity as Well as Diabetes. J. Obes. Metab. Syndr. 2021, 30, 12-19. [CrossRef]

57. Monami, M.; Nreu, B.; Scatena, A.; Cresci, B.; Andreozzi, F.; Sesti, G.; Mannucci, E. Safety issues with glucagon-like peptide-1 receptor agonists (pancreatitis, pancreatic cancer and cholelithiasis): Data from randomized controlled trials. Diabetes Obes. Metab. 2017, 19, 1233-1241. [CrossRef] [PubMed]

58. Wang, H.; Liu, Y.; Tianpei, H.; Yang, J.; Lu, R.; Zhan, S.; Haukka, J.; Hong, T. Incretin-based therapies and risk of pancreatic cancer in patients with type 2 diabetes: A meta-analysis of randomized controlled trials. Diabetes Obes. Metab. 2018, 20, 910-920. [CrossRef]

59. Abd El Aziz, M.; Cahyadi, O.; Meier, J.J.; Schmidt, W.E.; Nauck, M.A. Incretin-based glucose-lowering medications and the risk of acute pancreatitis and malignancies: A meta-analysis based on cardiovascular outcomes trials. Diabetes Obes. Metab. 2020, 22, 699-704. [CrossRef] [PubMed]

60. Sfairopoulos, D.; Liatis, S.; Tigas, S.; Liberopoulos, E. Clinical pharmacology of glucagon-like peptide-1 receptor agonists. Hormones 2018, 17, 333-350. [CrossRef]

61. Nreu, B.; Dicembrini, I.; Tinti, F.; Mannucci, E.; Monami, M. Cholelithiasis in patients treated with glucagon-like peptide-1 receptor: An updated meta-analysis of randomized controlled trials. Diabetes Res. Clin. Pract. 2020, 161, 108087. [CrossRef]

62. Hinnen, D. Glucagon-Like Peptide 1 Receptor Agonists for Type 2 Diabetes. Diabetes Spectr. 2017, 30, 202-210. [CrossRef]

63. Prasad-Reddy, L.; Isaacs, D.A. Clinical review of GLP-1 receptor agonists: Efficacy and safety in diabetes and beyond. Drugs Context. 2015, 4, 212283. [CrossRef] [PubMed]

64. Tsimihodimos, V.; Karanatsis, N.; Tzavela, E.; Elisaf, M. Antidiabetic Drugs and the Kidney. Curr. Pharm. Des. 2017, 23, 6310-6320. [CrossRef] 